\title{
Differential Photosynthetic Efficiency and Pigment Content in Two Common Purslane (Portulaca oleracea) Biotypes
}

\author{
Gregory R. Armel ${ }^{1}$, Dean A. Kopsell*, ${ }^{1}$, Jose J. Vargas ${ }^{1}$, Patrick L. Rardon ${ }^{2}$, Marc Ruggiero ${ }^{2}$, and \\ Steven A. Gower ${ }^{3}$ \\ ${ }^{1}$ Plant Sciences Department, The University of Tennessee, 2431 Joe Johnson Drive, Knoxville, TN 37996, USA \\ ${ }^{2}$ Stine Haskell Research Center, DuPont Crop Protection, 1090 Elkton Road, P.O. Box 30, Newark, DE 19714, USA \\ ${ }^{3} 113$ Center for Integrated Plant Systems, Michigan State University, East Lansing, MI 48824, USA
}

\begin{abstract}
Studies were conducted to determine how a serine to threonine mutation at position 264 on the Qb binding niche of the D1 protein [urea-resistant/triazine resistant (UR/TR biotype)] in common purslane (Portulaca oleracea) impacted carotenoid and chlorophyll pigment pools and measurements of photochemical and non-photochemical quenching (NPQ) following applications of various inhibitors of carotenoid biosynthesis (CBI) and the Photosystem II (PSII) inhibitor diuron when applied alone, or in mixtures, as compared to wildtype (WT) purslane. Non-photochemical quenching decreased 138 to $531 \%$ in comparison to the untreated checks following any herbicide application. Most CBI herbicides and diuron did not change chl $a$ and chl $b$ in the UR/TR biotype, while these same herbicide treatments tended to sharply decrease chlorophyll pigments in the WT population. Zeaxanthin levels were sharply elevated when CBI herbicides were applied alone to both purslane biotypes. $\beta$-carotene reduced in both biotypes following herbicide applications in comparison to the untreated check. Neoxanthin, antheraxanthin, and lutein were generally increased or remained similar to the untreated controls in the herbicide treated UR/TR biotype, while levels of these carotenoids tended to decrease in the herbicide treated WT population. Diuron alone increased neoxanthin, antheraxanthin, lutein, and zeaxanthin by 4 to $200 \%$ in the UR/TR biotype, but decreased these same carotenoids 25 to $62 \%$ in the WT population. The applications of CBI and PSII herbicides demonstrate that redox signaling in response to this mutation in the D1 protein may impact the retention of plant pigment concentrations in the light harvesting complexes of PSII, which would be vital for stress tolerance in this biotype.
\end{abstract}

Keywords: Antheraxanthin, $\beta$-carotene, lutein, neoxanthin, NPQ - non-photochemical quenching, violaxanthin, zeaxanthin.

\section{INTRODUCTION}

Carotenoids are plant pigments that expand the light harvesting capacity of chlorophyll (chl) and prevent membrane degradation of chloroplasts by quenching overflow energy from reactive oxygen species and triplet chl $[1,2]$. Carotenoid biosynthesis is initiated in the isoprenoid pathway starting with the formation of isopentenyl pyrophosphate (IPP). Molecules are formed from IPP in 5-carbon increments leading to the production of geranylgeranyl pyrophosphate (GGPP), whereby two molecules of GGPP are ultimately merged to form the basic structure of carotenoids [3]. Through a series of desaturations, cyclizations, and epoxidation steps several antioxidant carotenes and xanthophylls are produced which have an important role in preventing photoinhibition by either absorbing excess energy from chl, scavenging for reactive oxygen and chl species, and by performing numerous additional methods of non-photochemical quenching (NPQ) $[1,2]$.

Currently, carotenoid biosynthesis inhibiting (CBI) herbicides exist that competitively inhibit six of the approxi

*Address correspondence to this author at the Department of Plant Sciences, The University of Tennessee, Knoxville, TN 37996, USA;

Tel: (865) 974-7324; Fax: (865) 974-1947; E-mail: dkopsell@utk.edu mately twenty enzymes throughout the carotenoid biosynthesis pathway [4]. These CBI herbicides are either applied preemergence (prior to emergence of the weeds or crops) or postemergence (POST) (following emergence of the weeds or crops) for control of broadleaf and grass weeds in a variety of non-crop (aquatics and total vegetation management, etc.) and crop (agronomic, fruit, and vegetable crops, and turf) environments depending on the herbicide [5]. When applied POST, bleached tissue generally appears in the meristem within 3 to 5 days after application and is followed by necrosis and plant death within a couple of weeks after application. Since these herbicides rarely provide economical, broad-spectrum weed control at rates safe to most crops they are often applied in mixtures with other herbicides to improve performance.

CBI herbicides are often applied in mixtures with herbicide inhibitors of Photosystem II (PSII) because these mixtures often result in synergistic herbicidal responses on both annual and perennial weed species [6-8]. In fact, the symptoms produced with these CBI plus PSII mixtures changes from the slow bleaching or chlorotic symptoms normally associated with most CBI or PSII inhibitor applied alone to a rapid necrosis that appears on leaves within 1 to 2 days after application. The level of synergistic herbicidal response ob- 
served with these CBI plus PSII inhibitor mixtures is often dependent on the ratio of herbicide application rates and the inherent level of sensitivity among various weeds to both the CBI and PSII inhibitors applied alone [4,6,9]. It was originally believed that this synergistic response between CBI and PSII inhibitors was mostly attributed to carotenoid inhibitors that target $p$-hydroxyphenylpyruvate dioxygenase (HPPD), whereby the inhibition of this enzyme prevents the conversion of the amino acid tyrosine to homogentisate which is further converted to either the co-factor plastoquinone or the antioxidant $\alpha$-tocopherol. Plastoquinone has two roles in managing photooxidative stress by shuttling electrons away from the $\mathrm{Qb}$ binding niche of the $\mathrm{D} 1$ protein (competing with PSII inhibitors for binding to this site) while concurrently assisting the enzyme phytoene desaturase (PDS) in the conversion of phytoene to phytofluene in the steps leading up to the production of various carotenes and xanthophylls [7]. However, similar synergy was observed with PSII inhibitor mixtures with other CBI herbicides that do not inhibit the production of homogentisate and its postcursors plastoquinone and $\alpha$-tocopherol [4]. Therefore, a better understanding of this synergistic response between CBIs and PSII inhibitors is needed.

One manner in which herbicidal mixtures can be evaluated to determine differences in physiological and biological response is by applying them to herbicide resistant weed biotypes in comparison to wildtype (WT) weed populations. Currently, there are only two weeds resistant to any CBI herbicides, and these weed biotypes are only resistant to inhibitors of the enzyme PDS [10]. There are three known binding sites for on the $\mathrm{Qb}$ binding niche of the $\mathrm{D} 1$ protein for PSII inhibitors: 1) site A (C1); 2) site B (C2); and 3) site A with a different binding mechanism (C3). Different chemical classes of PSII inhibitors only target one of these binding areas on the D1 protein [11]. Currently, there are 63, 21 , and 3 different weed species that are resistant to herbicides that target the $\mathrm{Qb}$ binding site on the $\mathrm{D} 1$ protein at $\mathrm{C} 1$, $\mathrm{C} 2$, and $\mathrm{C} 3$, respectively [10]. A variety of mutations in the D1 protein of PSII can adversely impact the type of binding observed with different chemical family that inhibit PSII and therefore impact how these herbicides will perform alone, or in mixtures with herbicides with different mechanisms of action [12]. However, [13] found that mixtures of the HPPD inhibitor mesotrione applied in sequential applications or tank mixtures with atrazine provided synergistic responses in a triazine resistant velvetleaf (Abutilon theophrasti) biotype with an altered serine to glycine change at position 264 on the $\mathrm{Qb}$ binding niche of the $\mathrm{D} 1$ protein, but this mixture did not produce synergistic responses in an atrazine resistant velvetleaf population which metabolized atrazine as its mechanism of resistance [13]. To date, these types of studies have only involved applications of the HPPD inhibitors with certain PSII inhibitors and therefore have not evaluated the potential variations that could occur with CBI herbicides that inhibit more than one site in the carotenoid biosynthesis pathway with PSII inhibitors that target multiple sites on the $\mathrm{Qb}$ binding niche of the $\mathrm{D} 1$ protein. In addition, these types of studies have not incorporated measurements of chl fluo- rescence and plant pigment levels to physiologically explain visual observations of synergy.

The goal of this research was to evaluate the visual response, levels of carotenoids and chls, and the variations in levels of chl fluorescence in a WT and a unique PSII resistant biotypes of common purslane (Portulaca oleracea) following the application of several CBIs applied alone and in mixtures with the PSII inhibitor diuron which targets C2. Since common purslane is a common weed associated with many horticultural crops it is important to fully understand the mechanisms behind resistant weed biotypes to aid in the discovery of alternative strategies for weed management [10].

\section{MATERIALS AND METHODS}

\section{Herbicide Assays and Applications}

Greenhouse and laboratory studies were conducted in 2008 at the University of Tennessee in Knoxville, TN $\left(35.98^{\circ} \mathrm{N}\right.$ lat.) to evaluate POST applications of several CBI herbicides alone and in mixtures with the PSII inhibitor diuron. The CBI herbicides chosen and their sites of action are as follows: 1) DFPC- zeta-carotene desaturase (ZDS) inhibitor; 2) norflurazon- PDS inhibitor; 3) clomazone- deoxy-Dxylulose-5-phosphate synthatase (DOXP synthase) (the active metabolite ketoclomazone is actually the active herbicide at this site of action). Herbicides rates were chosen to illicit less than $50 \%$ visual response with each individual active ingredient so that synergistic responses might be most pronounced in CBI plus PSII inhibitor mixtures [4].

Two seedling plants of two biotypes of common purslane were transplanted into individual $6.35-\mathrm{cm}$ by $6.35-\mathrm{cm}$ pots containing a high organic matter potting media. The WT biotype was purchased from a seed supplier (Herbiseed, Twyford, England), while a UR/TR resistant biotype was acquired from Michigan State University, whereby the mechanism of weed resistance is a serine to threonine change at position 264 on the $\mathrm{Qb}$ binding niche of the $\mathrm{D} 1$ protein which confers resistance to both triazine herbicides (targeting C1) and urea herbicides (targeting C2) [20]. Common purslane plants were not greater than $16 \mathrm{~cm}$ at the time of herbicide application. Herbicides were applied using a $\mathrm{CO}_{2-}$ charged backpack sprayer calibrated to deliver $215 \mathrm{~L} / \mathrm{ha}$ through 4 flat fan nozzles (Teejet, Wheaton, IL).

Herbicide treatments were replicated three times and arranged in a randomized complete block design. All treatments were repeated in time. Weed control was visually rated after treatment on a scale of 0 to $100 \%$ where $0 \%=$ no injury or weed control and $100 \%=$ crop death or complete weed control. Weed control was evaluated at 5 days after treatment as this timing highlighted the most prominent differences in visual symptomology between herbicides applied alone and in mixtures. Following visual evaluations weeds were harvested and immediately analyzed for measurements of chl fluorescence and photosynthetic efficiency. After these measurements, plant samples were then stored in a -80 ${ }^{\circ} \mathrm{C}$ freezer prior to analyzing tissue for carotenoid and chl pigments. 
Measurements of Chlorophyll Fluorescence and Photosynthetic Efficiency

After a dark acclimation period of $60 \mathrm{~min}$, whole plants of each biotype $\mathrm{x}$ herbicide treatment combination were measured for chl fluorescence parameters using a pulseamplitude-modulated (PAM) fluorimeter (Photon Systems Instruments, Brno, Czech Republic). Measurements started with dark-adapted leaf tissues characterized by low, minimum fluorescence emission signal, $F_{0}$. The $F_{0}$ value is interpreted as the fluorescence signal from open PSII reaction centers with their primary quinone acceptor, $Q_{A}$, fully oxidized. The open reaction centers have the maximum photochemical quenching and the minimum fluorescence yield. At the same time, non-photochemical quenching (NPQ) is fully relaxed with the effective antenna size at its maximum. Dark-adapted leaf tissues were then exposed to strong flash of light $\left(3,000 \mu \mathrm{mol} \times \mathrm{m}^{-2} \times \mathrm{s}^{-1}\right.$ for $\left.0.1 \mu \mathrm{s}\right)$ that transiently reduces plastoquinone pool and the primary quinone acceptor, $Q_{A}$. The quenching by photochemistry of the reaction centers is eliminated and the fluorescence yield reaches its maximum. $N P Q$ remains relaxed because the illumination is transient and the quenching mechanisms cannot respond on such a short time-scale. The effective antenna size thus remains at its maximum. The measured fluorescence signal, $F_{M}$, is now at its maximum. This $F_{M}$ signal is often called maximum fluorescence (yield). The variable fluorescence, $F_{V}$, signal defined as the difference $F_{M}-F_{0}$ combined with the maximum fluorescence, $F_{M}$, are used to calculate the maximum quantum yield of PSIII photochemistry $F_{V} / F_{M}$ (or QYmax). The dark relaxation following the saturating flash leads to a re-oxidation of the plastoquinone pool and of the primary quinone acceptor, $Q_{A}$. The decline of fluorescence signal from the $F_{M}$ level back to $F_{0}$ dark-adapted level reflects kinetics at which the reaction centers re-open. The computer program decreased the light intensity of a series of saturating flashes to eliminate transiently photochemical quenching by reducing the plastoquinone pool and the $Q_{A}$ acceptor. The fluorescence signal reached local maxima, which reveals the dynamics of $N P Q$ during light adaptation. The value of $N P Q$ is quantified by $F_{M}-F_{M \_} L n / F_{M}[14]$. All value presented for $F_{V} / F_{M}, N P Q$, and $Q_{P}$ are presented as a percent reduction in comparison to the untreated check for each weed biotype.

\section{Carotenoid Tissue Extraction and HPLC Analysis for Plant Pigments}

Leaf tissues were lyophilized for $96 \mathrm{~h}$ (model $12 \mathrm{~L}$ FreeZone; LabConCo, Kansas City, MO) and stored at $-80{ }^{\circ} \mathrm{C}$ prior to extraction and analysis. Pigments were extracted from freeze-dried tissues according to Kopsell et al. [15] and analyzed according to Emenhiser et al. [16]. A $0.1 \mathrm{~g}$ tissue subsample was re-hydrated with $0.8 \mathrm{~mL}$ of ultra pure $\mathrm{H}_{2} \mathrm{O}$ and placed in a water bath set at $40{ }^{\circ} \mathrm{C}$ for $20 \mathrm{~min}$. After incubation, $0.8 \mathrm{~mL}$ of the internal standard ethyl- $\beta-8^{\prime}$-apocarotenoate (Sigma Chemical Co., St. Louis, MO) was added to determine extraction efficiency. The addition of $2.5 \mathrm{~mL}$ of tetrahydrofuran (THF) was performed after sample hydration. The sample was then homogenized in a PotterElvehjem (Kontes, Vineland, NJ) tissue grinding tube using $\sim 20$ insertions with a pestle attached to a drill press (Sears, Roebuck and Co., Hoffman Estates, IL) set at 540 rpm. During homogenation, the tube was immersed in ice to dissipate heat. The tube was then placed into a clinical centrifuge for 3 min at $500 g_{\mathrm{n}}$. The supernatant was removed and the sample pellet was re-suspended in $2 \mathrm{~mL}$ THF and homogenized again with the same extraction technique. The procedure was repeated for a total of four extractions to obtain a colorless supernatant. The combined supernatants were reduced to 0.5 $\mathrm{mL}$ under a stream of nitrogen gas (N-EVAP 111; Organomation Inc., Berlin, MA), and brought up to a final volume of $5 \mathrm{~mL}$ with methanol (MeOH). A $2 \mathrm{~mL}$ aliquot was filtered through a $0.2-\mu \mathrm{m}$ polytetrafluoroethylene (PTFE) filter (Model Econofilter PTFE 25/20, Agilent Technologies, Wilmington, DE) using a 5-mL syringe (Becton, Dickinson and Company, Franklin Lakes, NJ) prior to highperformance liquid chromatography (HPLC) analysis.

An Agilent 1200 series HPLC unit with a photodiode array detector (Agilent Technologies, Wilmington, DE) was used for pigment separation. Chromatographic separations were achieved using an analytical scale $(4.6 \mathrm{~mm}$ i.d. x 250 $\mathrm{mm}) 5 \mu \mathrm{m}, 200 \AA$ polymeric $\mathrm{C}_{30}$ reverse-phase column (ProntoSIL, MAC-MOD Analytical Inc., Chadds Ford, PA), which allowed for effective separation of chemically similar pigment compounds. The column was equipped with a guard cartridge $(4.0 \mathrm{~mm}$ i.d. $\times 10 \mathrm{~mm}$ ) (ProntoSIL), and was maintained at $30^{\circ} \mathrm{C}$ using a thermostatted column compartment (Agilent Technologies, Wilmington, DE). All separations were achieved isocratically using a binary mobile phase of $11 \%$ methyl tert-butyl ethanol (MTBE), $88.9 \% \mathrm{MeOH}$, with $0.1 \%$ triethylamine (TEA) $(\mathrm{v} / \mathrm{v} / \mathrm{v})$. The flow rate was 1.0 $\mathrm{mL} \cdot \mathrm{min}^{-1}$, with a run time of $53 \mathrm{~min}$, followed by a $2 \mathrm{~min}$ equilibration prior to the next injection. Eluted compounds from a $10 \mu \mathrm{L}$ injection were detected at $453 \mathrm{~nm}$ (carotenoids, chl $b$, and internal standard) and $652 \mathrm{~nm}(\operatorname{chl} a)$ and data were collected, recorded, and integrated using ChemStation Software (Agilent Technologies, Wilmington, DE). Peak assignment for individual pigments was performed by comparing retention times and line spectra obtained from photodiode array detection using external standards (antheraxanthin, $\beta$-carotene, chl $a$, chl $b$, lutein, neoxanthin, violaxanthin, zeaxanthin) (ChromaDex Inc., Irvine, CA). Spinach standard reference material (Slurried Spinach 2385, National Institute of Science and Technology, Gaithersburg, MD) was used for method validation. Due to the small amount of tissue generated from the purslane plants all material harvested from all three replicates of each run were combined and both runs were averaged for statistical analysis. All pigment values were calculated on a fresh weight basis.

\section{Statistical Analysis}

All data were subjected to analysis of variance (ANOVA) and means were separated using Fisher's protected LSD test at the $\alpha=0.05$ significance level. When ANOVA revealed no significant study by treatment interaction, data were pooled over studies. For measurements of chlorophyll fluorescence and non-photochemical quenching mean values are also presented with standard deviations. 


\section{RESULTS}

\section{Visual Ratings and Fresh Weights}

No study by treatment interaction occurred for injury ratings for the UR/TR biotype (Table 1). Therefore, only the injury ratings for the WT population are presented by studies. All CBI herbicides provided 33 to $45 \%$ control of common purslane across all biotypes. Diuron provided 40 to $57 \%$ control of the WT biotype and similarly controlled the UR/TR biotype $48 \%$. Mixtures of all CBI herbicides with diuron provided 42 to $63 \%$ control of the WT biotype, but only 43 to $44 \%$ control of the UR/TR biotype.

\section{Carotenoid and Chlorophyll Content}

Zeaxanthin levels were sharply elevated in CBI treatments applied alone to both common purslane biotypes (Table 2). $\beta$-carotene was reduced in both biotypes following herbicide application in comparison to the untreated check. Neoxanthin, antheraxanthin, and lutein were generally increased or remained similar to the untreated controls in the herbicide treated UR/TR biotype, while levels of these carotenoids tended to decrease in the herbicide treated WT population. Diuron alone increased neoxanthin, antheraxanthin, lutein, and zeaxanthin by 4 to $200 \%$ in the UR/TR biotype, but decreased these same carotenoids 25 to $62 \%$ in the WT population. CBI herbicides applied in mixtures with diuron decreased amounts of $\beta$-carotene by 48 to $84 \%$. In general, most mixtures of CBI herbicides plus diuron increased antheraxanthin and zeaxanthin in the UR/TR biotypes, but decreased these same carotenoids in the WT population when compared to the untreated check.
Most CBIs applied alone and in mixtures with diuron decreased the amount of chl $a$ and chl $b$ in the WT population in comparison to the untreated check (Table 3). Furthermore, the ZDS inhibitor DFPC decreased chl $a$ and chl $b$ in both biotypes by 33 to $100 \%$. Diuron decreased chl $a$ and chl $b$ in the WT population by 56 to $70 \%$.

\section{Measurements of Chlorophyll Fluorescence and Photo- synthetic Efficiency}

$N P Q$ values decreased by 138 to $531 \%$ in the herbicide treated WT and UR/TR biotypes when compared to the untreated check (Table 4). Measurements of $Q_{P}$ severely decreased in CBI plus diuron treatments when compared to the untreated check for both biotype populations. Decreases in $Q_{P}$ were greater in the WT population than the UT/TR biotypes. These decreases in $Q_{P}$ appeared to coincide most frequently with those treatments that caused the most visual injury to common purslane (Table 1,4$) . F_{V} / F_{M}$ values were decrease 11 to $97 \%$ regardless of herbicide treatment in both the WT and UR/TR biotypes (Table 4).

\section{DISCUSSION}

In general, the visual injury observed from these CBI and diuron applied alone or in mixtures did not always provide obvious differences in visual symptom between the WT and UR/TR biotypes (Table 1). However, the manner in which each biotype responded to the photooxidative stress caused by these herbicide inhibitors was to produce different levels of various plants pigments [17-19]. Previous research with this UR/TR biotype uncovered decreases in fresh weight, $F_{V} / F_{M}$, and $\mathrm{CO}_{2}$ assimilation following applications of both

Table 1. Percent Injury for Two Common Purslane (Portulaca oleracea) Biotypes [wildtype (WT) and Urea/Triazine-resistant (UR/TR)] Treated with Mixtures of Carotenoid Biosynthesis Inhibitors Alone and in Mixtures with the Photosystem II Inhibitor Diuron at 5 Days After Treatment

\begin{tabular}{|c|c|c|c|c|}
\hline \multirow{4}{*}{ Herbicide Treatment ${ }^{\mathbf{b}}$} & \multicolumn{4}{|c|}{ Injury } \\
\hline & \multirow[b]{2}{*}{ Rate } & \multicolumn{2}{|c|}{ WT } & \multirow{2}{*}{$\frac{\mathrm{UR} / \mathrm{TR}^{\mathrm{a}}}{\text { Study } 1+2}$} \\
\hline & & Study 1 & Study 2 & \\
\hline & g ai/ha & \multicolumn{3}{|c|}{$\longrightarrow \%$} \\
\hline Norflurazon & 500 & 37 & 40 & 42 \\
\hline Clomazone & 125 & 35 & 33 & 45 \\
\hline Diuron & 448 & 40 & 57 & 48 \\
\hline Norflurazon + diuron & $500+448$ & 63 & 42 & 43 \\
\hline $\operatorname{LSD}_{0.05}$ & & 16 & 13 & 8 \\
\hline
\end{tabular}

${ }^{a}$ No study by treatment interaction occurred for percent control visual ratings for the UR/TR common purslane populations, therefore these data were pooled over studies.

${ }^{\mathrm{b}}$ All treatments included 1\% (v/v) crop oil concentrate.

${ }^{\mathrm{c}}$ The untreated check was not included in the statistical analysis. 
Table 2. Mean Values \pm Standard Variation of Key Carotenoids for Two Common Purslane (Portulaca oleracea) Biotypes [wildtype (WT) and Urea/Triazine-resistant (UR/TR)] Treated with Mixtures of Carotenoid Biosynthesis Inhibitors Alone and in Mixtures with the Photosystem II Inhibitor Diuron at 5 Days After Treatment

\begin{tabular}{|c|c|c|c|c|c|c|c|c|c|c|c|c|}
\hline \multirow[b]{2}{*}{ Herbicide $^{\text {b }}$} & \multicolumn{12}{|c|}{ Carotenoids (mg/100 g Fresh weight) } \\
\hline & WT & UR/TR & WT & UR/TR & WT & UR/TR & WT & UR/TR & WT & UR/TR & WT & $\begin{array}{c}\text { UR/ } \\
\text { TR }\end{array}$ \\
\hline Norflurazon & $\begin{array}{c}0.42 \pm \\
0.07\end{array}$ & $\begin{array}{c}0.71 \pm \\
0.21\end{array}$ & $\begin{array}{c}1.19 \pm \\
0.30\end{array}$ & $\begin{array}{c}1.28 \pm \\
0.31\end{array}$ & $\begin{array}{c}0.83 \pm \\
0.13\end{array}$ & $\begin{array}{c}1.25 \pm \\
0.01\end{array}$ & $\begin{array}{c}4.23 \pm \\
1.02\end{array}$ & $\begin{array}{c}4.65 \pm \\
0.95\end{array}$ & $\begin{array}{c}0.35 \pm \\
0.24\end{array}$ & $\begin{array}{c}0.61 \pm \\
0.19\end{array}$ & $\begin{array}{c}1.69 \pm \\
0.35\end{array}$ & $\begin{array}{c}1.75 \\
\pm \\
0.31\end{array}$ \\
\hline DFPC & $\begin{array}{c}0.86 \pm \\
0.08\end{array}$ & $\begin{array}{c}0.86 \pm \\
0.08\end{array}$ & nd & nd & $\begin{array}{c}0.83 \pm \\
0.07\end{array}$ & $\begin{array}{c}0.90 \pm \\
0.04\end{array}$ & $\begin{array}{c}4.96 \pm \\
0.56\end{array}$ & $\begin{array}{c}3.16 \pm \\
0.74\end{array}$ & $\begin{array}{c}0.75 \pm \\
0.80\end{array}$ & $\begin{array}{c}1.64 \pm \\
0.16\end{array}$ & $\begin{array}{c}2.63 \pm \\
0.52\end{array}$ & $\begin{array}{c}1.04 \\
\pm \\
0.44\end{array}$ \\
\hline Clomazone & $\begin{array}{c}1.34 \pm \\
0.58\end{array}$ & $\begin{array}{c}0.59 \pm \\
0.21\end{array}$ & $\begin{array}{c}2.13 \pm \\
0.23\end{array}$ & $\begin{array}{c}1.13 \pm \\
0.22\end{array}$ & $\begin{array}{c}1.27 \pm \\
0.32\end{array}$ & $\begin{array}{c}0.58 \pm \\
0.22\end{array}$ & $\begin{array}{c}6.98 \pm \\
0.63\end{array}$ & $\begin{array}{c}3.51 \pm \\
0.56\end{array}$ & $\begin{array}{c}0.12 \pm \\
0.04\end{array}$ & $\begin{array}{c}0.08 \pm \\
0.01\end{array}$ & $\begin{array}{c}3.94 \pm \\
0.41\end{array}$ & $\begin{array}{c}1.82 \\
\pm \\
0.41\end{array}$ \\
\hline $\begin{array}{l}\text { Norflurazon }+ \\
\text { diuron }\end{array}$ & $\begin{array}{c}1.15 \pm \\
0.56\end{array}$ & $\begin{array}{c}1.18 \pm \\
0.19\end{array}$ & $\begin{array}{c}1.16 \pm \\
0.49\end{array}$ & $\begin{array}{c}1.16 \pm \\
0.24\end{array}$ & $\begin{array}{c}0.71 \pm \\
0.39\end{array}$ & $\begin{array}{c}0.69 \pm \\
0.29\end{array}$ & $\begin{array}{c}3.54 \\
\pm 1.30\end{array}$ & $\begin{array}{c}3.58 \pm \\
0.58\end{array}$ & $\begin{array}{c}0.10 \pm \\
0.02\end{array}$ & $\begin{array}{c}0.18 \pm \\
0.04\end{array}$ & $\begin{array}{c}1.51 \pm \\
0.71\end{array}$ & $\begin{array}{c}1.40 \\
\pm \\
0.19\end{array}$ \\
\hline $\begin{array}{l}\text { DFPC + di- } \\
\quad \text { uron }\end{array}$ & $\begin{array}{c}0.67 \pm \\
0.30\end{array}$ & $\begin{array}{c}2.19 \pm \\
0.00\end{array}$ & $\begin{array}{c}0.37 \pm \\
0.11\end{array}$ & nd & $\begin{array}{c}0.28 \pm \\
0.13\end{array}$ & $\begin{array}{c}2.10 \pm \\
0.00\end{array}$ & $\begin{array}{c}2.35 \pm \\
0.88\end{array}$ & $\begin{array}{c}8.38 \pm \\
0.00\end{array}$ & $\begin{array}{c}0.07 \pm \\
0.02\end{array}$ & $\begin{array}{c}0.13 \pm \\
0.00\end{array}$ & $\begin{array}{c}0.63 \pm \\
0.23\end{array}$ & $\begin{array}{c}1.02 \\
\pm \\
0.00\end{array}$ \\
\hline $\begin{array}{l}\text { Clomazone }+ \\
\text { diuron }\end{array}$ & $\begin{array}{c}0.60 \pm \\
0.20\end{array}$ & $\begin{array}{c}1.17 \pm \\
0.04\end{array}$ & $\begin{array}{c}0.41 \pm \\
0.22\end{array}$ & $\begin{array}{c}0.94 \pm \\
0.01\end{array}$ & $\begin{array}{c}0.36 \pm \\
0.17\end{array}$ & $\begin{array}{c}1.15 \pm \\
0.01\end{array}$ & $\begin{array}{c}2.45 \pm \\
0.90\end{array}$ & $\begin{array}{c}4.74 \pm \\
0.01\end{array}$ & $\begin{array}{c}0.07 \pm \\
0.00\end{array}$ & $\begin{array}{c}0.13 \pm \\
0.01\end{array}$ & $\begin{array}{c}0.80 \pm \\
0.27\end{array}$ & $\begin{array}{c}1.44 \\
\pm \\
0.08\end{array}$ \\
\hline
\end{tabular}

${ }^{a}$ Plants from all three repetitions of each common purslane biotype were pooled together from study 1 and study 2 for analysis of carotenoid content. nd $=$ below detection limits. ${ }^{\mathrm{b}}$ Rate, g ai/ha: Norflurazon, 500; DFPC, 62; Clomazone, 125; Diuron, 448; Norflurazon + diuron, $500+448$; DFPC + diuron, $62+448$; Clomazon + diuron, $125+448$.

All treatments included $1 \%(\mathrm{v} / \mathrm{v})$ crop oil concentrate.

atrazine and linuron (another substituted urea herbicide similar to diuron and this injury dissipated by 2 weeks after treatment) [20]. However, these researches did not report how carotenoid content varied during that period of time after PSII inhibitor application. Concentrations of violaxanthin, neoxanthin, antheraxanthin, lutein, $\beta$-carotene, and zeaxanthin often varied between the two biotypes depending on the applied composition of herbicides in our studies (Table 2). In general, CBI applications increased concentrations of neoxanthin, antheraxanthin, and lutein in the UR/TR biotype, while all of these pigments were generally decreased in the WT population with most CBI applications. In addition, zeaxanthin was increased, while $\beta$-carotene was decreased by most CBI applications in both weed biotypes. Violaxanthin tended to increase in the WT population and decrease in the UR/TR biotype following most CBI applications.

Other researchers have reported on how differential carotenoid content impacts photoprotection and plant develop- ment. The xanthophyll cycle pigments antheraxanthin, violaxanthin, and zeaxanthin play an important role in photoprotection, light harvesting, and the assembly of light harvesting antenna complexes (LHC) [21]. The xanthophyll cycle pigments are integral in allowing plants to fluctuate between light harvesting complexes under low light environments, while affording the flexibility to convert to dissipative activities in high light environments [22]. In addition, LHC of photosynthesis are primarily composed of conserved concentrations of neoxanthin, violaxanthin, and lutein, whereby each xanthophyll plays a unique functional role [19, 21]. However, either by conversion from violaxanthin and antheraxanthin through violaxanthin de-epoxidase, or by conversion from $\beta$-carotene, zeaxanthin may substitute for violaxanthin and lutein and thereby maintain the integrity of the D1 protein during periods of stress [23,24]. However, in our studies the treatments that produced the most visual damage to purslane generally created higher concentrations 
Table 3. Mean values \pm standard deviation for chlorophyll $a(\mathrm{chl} a)$ and $b(\mathrm{chl} b)$ for two common purslane (Portulaca oleracea) biotypes [wildtype (WT) and urea/triazine-resistant (UR/TR)] with mixtures of carotenoid biosynthesis inhibitors alone and in mixtures with the Photosystem II inhibitor diuron at 5 days after treatment.

\begin{tabular}{|c|c|c|c|c|}
\hline Herbicide Treatment ${ }^{b}$ & \multicolumn{2}{|c|}{ Chl $a$} & \multicolumn{2}{|c|}{ Chl $b$} \\
\hline Norflurazon & $55.24 \pm 12.50$ & $50.85 \pm 13.05$ & $15.22 \pm 3.07$ & $21.08 \pm 4.47$ \\
\hline Clomazone & $90.32 \pm 8.17$ & $35.13 \pm 4.36$ & $26.62 \pm 2.98$ & $12.83 \pm 1.26$ \\
\hline Diuron & $25.98 \pm 11.35$ & $50.93 \pm 4.47$ & $13.08 \pm 4.99$ & $22.52 \pm 1.79$ \\
\hline Norflurazon + diuron & $33.44 \pm 15.36$ & $28.74 \pm 2.16$ & $13.19 \pm 5.42$ & $12.29 \pm 1.72$ \\
\hline $\mathrm{DFPC}+$ diuron & $19.46 \pm 8.60$ & $63.35 \pm 0.00$ & $9.23 \pm 3.71$ & $39.67 \pm 0.00$ \\
\hline $\operatorname{LSD}_{0.05}$ & 22.57 & 54.39 & 8.28 & 18.42 \\
\hline
\end{tabular}

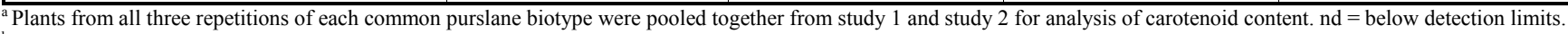
${ }^{\mathrm{b}}$ Rate, g ai/ha: Norflurazon, 500; DFPC, 62; Clomazone, 125; Diuron, 448; Norfluszon + diuron, 500 + 448; DFPC + diuron, 62 + 448; Clomazon + diuron, $125+448$. All treatments included 1\% (v/v) crop oil concentrate.

of antheraxanthin, lutein, and neoxanthin in the UR/TR biotype, while decreasing these two pigments in the WT population (Table 2). Other researchers have demonstrated that lutein can also substitute for zeaxanthin in order to restore the functionality of non-photochemical quenching in plants [25]. In general, plant pigments are in a constant state of flux responding to both abiotic and biotic stressors alike and no one pigment configuration is always favored among individual biotypes of various species in response to the same stressors.

Differences in plant response to stressors are often best observed when comparing mutants or resistant weed biotypes to the WT. For example, a serine to threonine mutation at site 264 on the Qb binding niche of the D1 protein in potato cells led to no reductions in photosynthetic electron transport or n-cell growth penalties when compared to the WT [26]. However, a serine to glycine mutation at the same site caused limited $Q_{P}$ and $N P Q$ and a hypersensitivity to photoinhibition [27]. This hypersensitivity was likely due to a greater concentration of Qb-non-reducing (inactive) binding centers that are produced in this mutant when compared to the WT that led to reductions in electron transport [28]. While this mutation may provide tolerance to herbicides which would normally kill the WT population, the mutation may also provide fitness penalties that are not desirable in overcoming other plant stressors [29]. However, some mutations in the D1 protein may offer some advantages that are not always obvious. For example, Narusaka et al. [30] theorized that certain mutations in $\mathrm{Qb}$ may increase or decrease hydrophilic interactions on the D1 protein thereby initiating a redox signaling through protein phosphorylation which triggers gene expression and facilitates the retention of certain pigment combinations in the LHC. In our studies, applications of the PSII inhibiting herbicide diuron to the UR/TR biotype with a serine to threonine mutation increased neoxanthin, antheraxanthin, zeaxanthin, and lutein concentrations by 82 to $258 \%$ when compared to the untreated check (Table 2). These xanthophyll cycle pigments, especially zeaxanthin, are directly involved in energy dissipation.

\section{CONCLUSIONS}

Harsh impacts of environmental stressors and applications of certain herbicides which inhibit photosynthesis and/or carotenoid biosynthesis can reduce photosynthetic rates and increase the need for increased energy dissipation via xanthophyll cycle pigments [31]. Therefore, it may be possible that mutations to the $\mathrm{Qb}$ binding niche of the $\mathrm{D} 1$ protein may result in the retention of optimal pigment combinations that would improve plant stress tolerance, and ultimately ensure survival for reproduction. These findings demonstrate that the selection of herbicide resistant weed biotypes might not only limit weed control options for growers, but may allow for easier proliferation of weed biotypes that are better able to deal with environmentally stressful conditions that would normally limit the competitiveness of their wildtype relatives in similar crop environments.

\section{ACKNOWLEDGEMENTS}

This work was supported with herbicide samples provided by DuPont Crop Protection and resistant weed seeds provided by the Plant Diagnostic Services at Michigan State University. The authors would like to thank Dr. Brandon Smith and Dr. Annette Wszelaki and their research teams for their assistance with the chlorophyll fluorescence measurements. We would also like to thank Douglas Renfro, Greg Allen, and Kristin Abney for their efforts on the carotenoid 
Table 4. Chlorophyll fluorescence parameters \pm standard deviation for two common purslane (Portulaca oleracea) biotypes [wildtype (WT) and urea/triazine-resistant (UR/TR)] treated with mixtures of carotenoid biosynthesis inhibitors alone and in mixtures with the Photosystem II inhibitor diuron at 5 days after treatment.

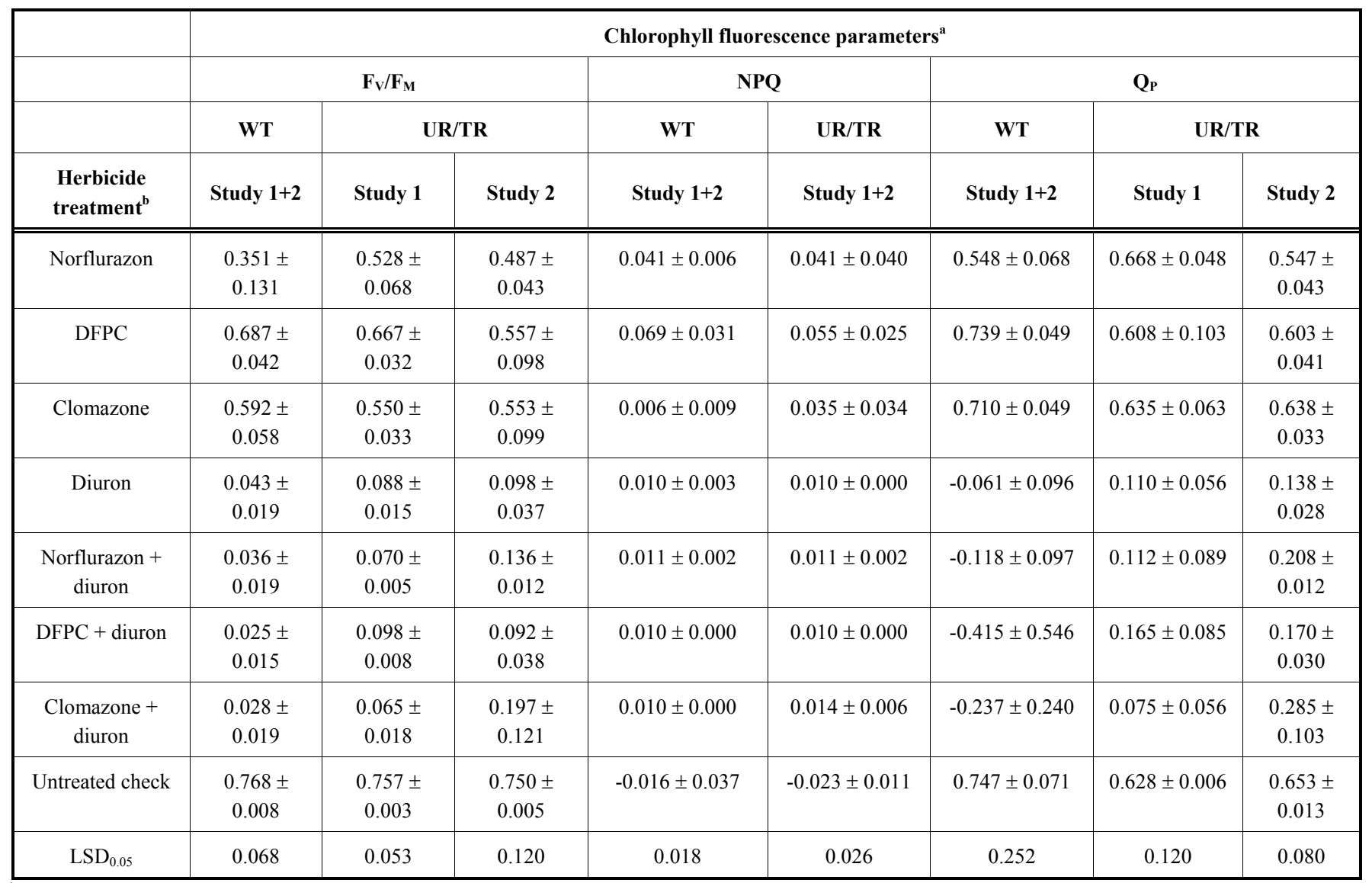

${ }^{a}$ Plants from all three repetitions of each common purslane biotype were pooled together from study 1 and study 2 for analysis of carotenoid content.

${ }^{\mathrm{b}}$ Rate, g ai/ha: Norflurazon, 500; DFPC, 62; Clomazone, 125; Diuron, 448; Norflurazon + diuron, 500 + 448; DFPC + diuron, $62+448 ;$ Clomazon + diuron, $125+448$.

All treatments included $1 \%(\mathrm{v} / \mathrm{v})$ crop oil concentrate.

and chlorophyll analyses. We would also extend our gratitude to Dr. Bal Kamireddy for preparation of DFPC.

\section{CONFLICT OF INTEREST}

The author(s) confirm that this article content has no conflicts of interest.

\section{REFERENCES}

[1] Britton G, Barry P, Young AJ. Carotenoids and chlorophyll: herbicidal inhibition of pigment biosynthesis. In: Dodge AD, Ed. Herbicide and plant metabolism. Cambridge, UK: Cambridge University Press vol. 38: 1989; pp. 50-72.

[2] Young AJ. The photoprotective role of carotenoids in higher plants. Physiol Plant 1991; 83: 702-8.

[3] Cunningham FX, Gantt E. Genes and enzymes of carotenoid biosynthesis in plants. Annu Rev Plant Physiol Plant Mol Biol 1998; 49: 557-83.

[4] Armel GR, Rardon PL, McComrick MC, Ferry NM. Differential response of several carotenoid biosynthesis inhibitors in mixtures with atrazine. Weed Technol 2007; 21: 947-53.

[5] Vencill WK, Ed. Herbicide handbook. $8^{\text {th }}$ ed. Champaign, IL: Weed Science Society of America 2002.

[6] Abendroth JA, Martin AR, Roeth FW. Plant response to combinations of mesotrione and photosystem II inhibitors. Weed Technol 2006; 20: 267-74.
[7] Armel GR, Hall GJ, Wilson HP, Cullen N. Mesotrione plus atrazine mixtures for control of Canada thistle (Cirsium arvense). Weed Sci 2005; 53: 202-11.

[8] Salzman FP, Renner KA. Response of soybean to combinations of clomazone, metribuzin, linuron, alachlor, and atrazine. Weed Technol 1992; 6: 922-9.

[9] Armel GR, Richardson RJ, Wilson HP, Whaley CM, Hines TE. Mesotrione combinations with atrazine and bentazon for yellow and purple nutsedge (Cyperus esculentus and C.rotundus) control in corn (Zea mays). Weed Technol 2008; 22: 391-6.

[10] Heap I. International survey of herbicide resistant weeds. WeedScience.org [home page on internet] 1993-2012 [updated $9^{\text {th }}$ April 2012; cited $9^{\text {th }}$ April 2012]. Available from: http://www.weedscience.org

[11] Mallory-Smith CA, Retzinger EJ. Revised classification of herbicides by site of action for weed resistance management strategies. Weed Technol 2003; 17: 605-19.

[12] Wilski S, Johanningmeier U, Hertel S, Oettmeier W. Herbicide binding in various mutants of the photosystem II D1 protein of Chlamydomonas reinhardtii. Pestic Biochem Physiol 2006; 84(3):157-64.

[13] Woodyard AJ, Hugie JA, Richers DE. Interactions of mesotrione and atrazine in two weed species with different mechanisms for atrazine resistance. Weed Sci 2009; 57: 369-78.

[14] Anonymous. Fluro Cam instruction manual. Version 1.8. Brno, Czech Republic: Photon Systems Instruments 2006.

[15] Kopsell DA, Kopsell DE, Lefsrud MG, Curran-Celentano J, Dukach LE. Variation in lutein, $\beta$-carotene, and chlorophyll concentrations among Brassica oleracea cultigens and seasons. HortScience 2004; 39: 361-4. 
[16] Emenhiser C, Simunovic N, Sander LC, Schwartz SJ. Separation of geometric carotenoid isomers in biological extracts using a polymeric $\mathrm{C}_{30}$ column in reverse-phase liquid chromatography. J Agric Food Chem 1996; 44: 3887-93.

[17] Meir S, Ronen R, Lurie S, Philosoph-Hadas S. Assessment of chilling injury during storage: chlorophyll fluorescence characteristics of chilling-susceptible and triazole-induced chilling tolerant basil leaves. Postharvest Biol Technol 1997; 10: 213-20.

[18] Armel GR, Richardson RJ, Wilson HP, Trader BW, Whaley CM, Hines TE. Evaluation of acetolactate synthase-inhibiting herbicides for weed control in transplanted bell pepper. HortTechnology 2009; 19: 400-4

[19] Bungard RA, Ruban AV, Hibberd JM, Press MC, Horton P, Scholes JD. Unusual carotenoid composition and a new type of xanthophyll cycle in plants. Proc Natl Acad Sci USA 1999; 96: 1135-9.

[20] Masabni JG, Zandstra BH. A serine-to-threonine mutation in linuron-resistant Portulaca oleracea. Weed Sci 1999; 47: 393-400.

[21] Pogson BJ, Niyogi KK, Bjőrkman O, DellaPenna D. Altered xanthophyll compositions adversely affect chlorophyll accumulation and nonphotochemical quenching in Arabidopsis mutants. Proc Natl Acad Sci USA 1998; 95: 12229-133324.

[22] Jahns P, Latowski D, Strzalka K. Mechanism and regulation of the violaxanthin cycle: the role of antenna proteins and lipids. Biochim Biophys Acta 2009; 1787(1): 3-14.

[23] Depka B, Jahns P, Trebst A. $\beta$-Carotene to zeaxanthin conversion in the rapid turnover of the D1 protein of photosystem II. FEBS Lett 1998; 424: 267-70.

[24] Polle JE, Niyogi KK, Melis A. Absence of the pigments lutein, violaxanthin, and neoxanthin affects the functional chlorophyll antenna size of photosystem II but not photosytem I in green alga Chlamydomonas reinhardtii. Plant Cell Physiol 2001; 5: 482-91.

[25] Li Z, Ahn TK, Avenson TJ, et al. Lutein accumulation in the absence of zeaxanthin restores nonphotochemical quenching in the Arabidopsis thaliana npq1 mutant. Plant Cell 2009; 21(6): 179882.

[26] Smeda RJ, Hasegawa PM, Goldsbrough PB, Singh NK, Weller SC A serine-to-threonine substitution in the triazine herbicide-binding protein in potato cells results in atrazine resistance without impairing productivity. Plant Physiol 1993; 103: 911-7.

[27] Váradi G, Polyánka E, Darkó É, Lehoczki E. Atrazine resistance entails a limited xanthophyll cycle activity, a lower PSII efficiency and an altered pattern of excess excitation dissipation. Physiol Plant 2003; 118: 47-56.

[28] Van Rensen JJS, Vredenberg WJ. Higher concentration of $\mathrm{Q}^{-}$ nonreducing photosystem II center in triazine-resistant Chenopodium album plants as revealed by analysis of chlorophyll fluorescence kinetics. J Plant Physiol 2009; 166: 1616-23.

[29] Warwick SI, Black L. The relative competitiveness of atrazine susceptible and resistant populations of Chenopodium album and C. strictum. Can J Bot 1981; 59: 689-93.

[30] Narusaka Y, Narusaka M, Satoh K, Kobayashi H. In vitro random mutagenesis of the D1 protein of the photosystem II reaction center confers phototolerance on the cyanobacterium Synchocystis sp. PCC 6803. J Biol Chem 1999; 274(33): 23270-5.

[31] Demmig-Adams B. Carotenoids and photoprotection in plants: a role for the xanthophyll zeaxanthin. Biochim Biophys Acta 1990; $1020: 1-24$.

(C) Armel et al.; Licensee Bentham Open.

This is an open access article licensed under the terms of the Creative Commons Attribution Non-Commercial License (http://creativecommons.org/ licenses/by-nc/3.0/), which permits unrestricted, non-commercial use, distribution and reproduction in any medium, provided the work is properly cited. 